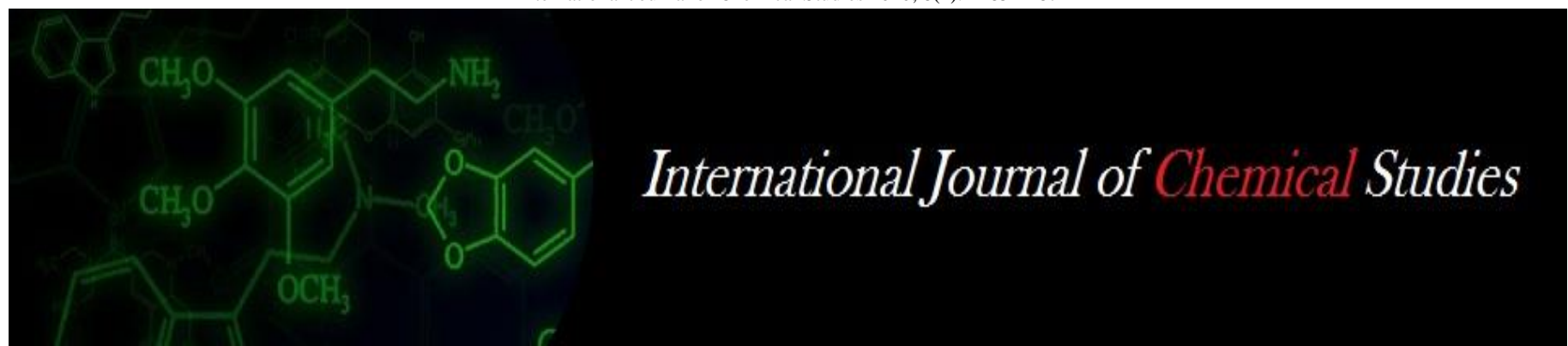

P-ISSN: 2349-8528

E-ISSN: 2321-4902

www.chemijournal.com

IJCS 2020; 8(2): 2485-2487

(C) 2020 IJCS

Received: 07-01-2020

Accepted: 09-02-2020

\section{G Ramesh}

Scientist (Crop Production),

KVK, Darsi, Andhra Pradesh,

India

\section{Dr. Ch. Pulla Rao}

Professor (Rtd.), Department of Agronomy, Agricultural College

Bapatla, Andhra Pradesh, India

Dr. PV N Prasad

Principal Scientist, Agricultural College Farm, Bapatla, Andhra

Pradesh, India

\section{Dr. PRK Prasad}

Professor, Department of Soil

Science \& Agril. Chemistry,

Agril. College Bapatla Andhra

Pradesh, India
Corresponding Author:

G Ramesh

Scientist (Crop Production),

KVK, Darsi, Andhra Pradesh,

India

\section{Influence of INM on yield attributes, yield, economics and nitrogen use efficiency of foxtail millet}

\author{
G Ramesh, Dr. Ch. Pulla Rao, Dr. PV N Prasad and Dr. PRK Prasad
}

DOI: https://doi.org/10.22271/chemi.2020.v8.i2al.9122

\begin{abstract}
Field experiments were conducted at Obannavaripalem village, Nagauppalapadu Mandal, Prakasam district, Andhra Pradesh during kharif seasons of 2014 and 2015 to study the effect of different integrated nutrient management practices with special reference to $\mathrm{N}$ for kharif foxtail millet on yield and economics. The results revealed that on clay loamy soils of Krishna Agroclimatic zone of Andhra Pradesh, application of $125 \% \mathrm{RDN}+\mathrm{FYM} @ 5 \mathrm{t} \mathrm{ha}^{-1}$ recorded the highest foxtail millet yield attributes at maturity, grain, stover yield and $\mathrm{B}: \mathrm{C}$ ratio among the treatments.
\end{abstract}

Keywords: Foxtail millet, nitrogen management, FYM, yield, economics

\section{Introduction}

Foxtail millet is one of the oldest cultivated small millets both for food and fodder. It ranks second in the total world production of millets and it continues to have an important place in world agriculture providing food for millions of people in arid and semiarid regions. It is native to China and regarded as an elite drought-tolerant crop. Andhra Pradesh, Karnataka and Tamil Nadu are the major foxtail millet growing states in India contributing about 79 per cent of the total area (Munirathnam et al, 2006) ${ }^{[6]}$.

The yield potential of foxtail millet is low in India compared to the potentially achievable yield because of inadequate application of fertilizers, conventional cultivation of low yielding cultivars and lack of good management practices. Maximum yield potential can be achieved by using higher rates of fertilizer application. The crop is tolerant to drought and mostly grown under marginal soils and waste lands having very low levels of nutrients and organic matter and poor water holding capacity. Although the crop is grown since time immemorial in India and especially in Andhra Pradesh, not much attention was paid to improve the productivity.

\section{Material and Methods}

The trial was conducted during kharif 2014 and 2015 on clay loam soils at Obennapalem village, Nagauppalapadu Mandal, Prakasam district, Andhra Pradesh. The treatments included five levels of fertilizer viz., Control $\left(\mathrm{T}_{1}\right), 100 \% \mathrm{RDN}\left(\mathrm{T}_{2}\right), 100 \% \mathrm{RDN}+\mathrm{FYM} @ 5 \mathrm{t} \mathrm{ha} \mathrm{h}^{-1}\left(\mathrm{~T}_{3}\right)$, $125 \%$ RDN $\left(\mathrm{T}_{4}\right)$ and $125 \% \mathrm{RDN}+\mathrm{FYM} @ 5 \mathrm{tha}^{-1}$ laid out in Randomized Block Design and replicated four times. The foxtail millet variety sreelakshmi was sown in the line opened at $22.5 \mathrm{~cm}$ apart. The recommended dose of $\mathrm{P}_{2} \mathrm{O}_{5} @ 20 \mathrm{~kg} \mathrm{ha}^{-1}$ was applied to all the treatments uniformly. Nitrogen and FYM were applied at the time of sowing. The yield attributes, grain and stover yield were recorded at maturity.

\section{Results and Discussion}

Length of the ear head $(\mathrm{cm})$

Application of 125\% RDN + FYM @ $5.0 \mathrm{t} \mathrm{ha}^{-1}$ recorded the highest ear head length and it was on par with $125 \%$ RDN. However, these two treatments were significantly higher over the $100 \%$ RDN + FYM @ $5.0 \mathrm{t} \mathrm{ha}^{-1}$ and 100\% RDN during the first and second years of experiment. Its role in various biochemical processes in the plant has been described by many scientists. Nitrogen by virtue of its link in the process of photosynthetic process and cell division, cell partitioning increased the drymatter accumulation at higher $\mathrm{N}$ levels. 
This higher drymatter and its partitioning might have resulted in more length of the panicle in foxtail millet and also this might be due to more vigorous and luxuriant vegetative growth due to nitrogen application, which in turn favoured a better partitioning of assimilates from source to sink. The present results were in accordance with the findings of Subramanian and Ganesaraja (1992), Kalaghatagi et al. (2000) ${ }^{[5]}$ and Hasan et al. (2013) ${ }^{[4]}$.

\section{Number of filled grains per ear head}

Significantly highest number of filled grains per panicle was observed in application of 125\% RDN + FYM @ $5.0 \mathrm{t} \mathrm{ha}^{-1}$ over control and was found on par with $125 \%$ RDN, 1005 RDN + FYM@ $5.0 \mathrm{t} \mathrm{ha}^{-1}$ and 100\% RDN. The beneficial effect of application of 125\% RDN + FYM @ $5.0 \mathrm{t} \mathrm{ha}^{-1}$ on growth characters was subsequently reflected in improved number of filled grains per ear head. Which might be due to improved source sink relationship, with efficient translocation of photosynthates to the grains (Hasan et al. 2013) ${ }^{[4]}$.

\section{Weight of the ear head}

Significantly the highest ear head weight was observed with application of 125\% RDN + FYM @ $5.0 \mathrm{t} \mathrm{ha}^{-1}$, but it was on par with $125 \%$ RDN. Ear head weight with $100 \%$ RDN + FYM @ $5.0 \mathrm{t} \mathrm{ha}^{-1}$ and $100 \%$ RDN were statistically comparable. Increase in panicle weight with increase in nitrogen levels might be due to better growth of the crop, efficient dry matter partitioning and better translocation to the sink, leading to the formation of more number of filled grains and large sized grains (Turgut et al. 2006) ${ }^{[7]}$.

\section{Test Weight (1000 grain weight)}

Application of $125 \%$ RDN + FYM @ $5.0 \mathrm{t} \mathrm{ha}^{-1}$ consistently recorded the highest thousand grain weight. While the lowest was observed with no nitrogen application. The increase in thousand grain weight might due to due to higher nitrogen levels and efficient drymatter partitioning besides better translocation to the sink, leading to the formation of large sized grains as a results of adequate availability of nutrients at the time of grain filling. This ultimately accountable in higher test weight (Divya and Maurya, 2013) ${ }^{[3]}$.

\section{Grain and biological yield}

There was a significant increased in seed yield with increasing N levels. Application of 125\% RDN + FYM @ 5.0 $\mathrm{t} \mathrm{ha}^{-1}$ recorded the highest grain yield of 2701 and $2709 \mathrm{~kg} \mathrm{ha}^{-}$ 1 during the first and second years of study respectively, which was significantly superior to the other nitrogen levels tried, followed by $125 \% \mathrm{RDN}$. The lowest grain yield was observed with no nitrogen application. Applying 100\% RDN gave 1666 and $1719 \mathrm{~kg} \mathrm{ha}^{-1}$ grain yield during first and second years of the study, respectively and was found significantly the lowest. Application of 125\% RDN + FYM @ $5.0 \mathrm{t} \mathrm{ha}^{-1}$ increased the seed yield by 38.3 and 36.5 per cent over no nitrogen application in 2014 and 2015 respectively.
The improvement in seed yield with enhanced nitrogen application might be attributed to better availability and uptake of nutrients which in turn might have lead to efficient metabolism. Higher levels of biomass accumulation and efficient translocation of photosynthates from source to sink might be responsible for the increased seed yields. The above results are in conformity with the findings of several researchers such as Kalaghatagi et al. (2000) ${ }^{[5]}$, Basavarajappa et al. (2002) ${ }^{[2]}$.

Among the nitrogen levels, application of $125 \%$ RDN + FYM (a) $5.0 \mathrm{t} \mathrm{ha}^{-1}$ recorded the highest stover yield (4805 and 4825 $\mathrm{kg} \mathrm{ha} \mathrm{a}^{-1}$ during first and second years of study) which was statically on par with application of $125 \%$ RDN and was significantly higher than no nitrogen application. Significantly lowest straw yield of foxtail millet $\left(2881\right.$ and $3188 \mathrm{~kg} \mathrm{ha}^{-1}$ during the first and second years of the experimentation, respectively) was obtained with no nitrogen application.

\section{Economics}

The highest net returns were registered with application of $125 \%$ RDN. The next best treatment was application of $125 \%$ $\mathrm{RDN}+\mathrm{FYM} @ 5 \mathrm{tha}^{-1}$. The lowest net returns were recorded with no nitrogen application. The higher net returns might be due to higher grain and straw yields registered under higher nitrogen levels. Present investigation confirms the results reported by Divya and Maurya (2013) ${ }^{[3]}$.

The net returns and $\mathrm{B}: \mathrm{C}$ ratio (Table 3) revealed that the highest net monetary returns and benefit: cost ratio were recorded with the treatment where recommended dose of $125 \%$ RDN applied through chemical fertilizers than rest of the treatments. This could be due to the manifestation of higher grain and stover yields fetching of higher net returns at increased level of nitrogen. The similar results are reported by Divya and Maurya (2013) ${ }^{[3]}$.

\section{Nitrogen use efficiency}

The agronomic $\mathrm{N}$ use efficiency $\left(\mathrm{AE}_{\mathrm{N}}\right)$ calculated during both the years of study (Table 4). Among the treatments with $125 \%$ RDN registered higher AEN as compared to rest of the treatments, where as the nitrogen recovery efficiency $\left(\mathrm{RE}_{\mathrm{N}}\right)$ estimated during both the years of study (Table 4). In general, relatively higher $\mathrm{RE}_{\mathrm{N}}\left(0.35 \mathrm{~kg} \mathrm{~kg}^{-1}\right)$ was registered with higher nitrogen application treatment i.e $125 \%$ RDN as compared to other treatments. The NUE in a crop/cropping system can be improved by maintaining the synchrony between soil $\mathrm{N}$ supply and crop $\mathrm{N}$ demand, which can be attained by suitable quantity and proper timing of application of organic and inorganic fertilizers. In general, the higher soil $\mathrm{N}$ content at critical growth stages led to higher above ground biomass, grain yield and $\mathrm{N}$ uptake, hence higher NUE of foxtail millet with $125 \%$ RDN than other treatments (control, $100 \%$ RDN, $100 \%$ RDN + FYM @ $5 \mathrm{t} \mathrm{ha}^{-1}$ and $125 \%$ RDN + FYM @ $\left.5 \mathrm{t} \mathrm{ha}^{-1}\right)$. The results are in confirmity with the findings of Bhattacharya et al., (2006) ${ }^{[1]}$.

Table 1: Yield attributes of foxtail millet as influenced by different integrated nutrient management practices during kharif 2014 and 2015

\begin{tabular}{|c|c|c|c|c|}
\hline Treatments & $\begin{array}{c}\text { Length of the ear } \\
\text { head }(\mathbf{c m})\end{array}$ & $\begin{array}{c}\text { Weight of the ear head } \\
(\mathbf{g})\end{array}$ & $\begin{array}{c}\text { Number of filled grains ear } \\
\text { head }^{-1}\end{array}$ & $\begin{array}{c}\text { 1000- grain weight } \\
(\mathbf{g})\end{array}$ \\
\hline \multicolumn{5}{|c|}{$\mathbf{2 0 1 4}$} \\
\hline Control & 7.2 & 1.6 & 501.5 & 2.50 \\
\hline 100\% RDN & 13.9 & 4.3 & 795.5 & 2.75 \\
\hline 100\% RDN + FYM @ 5.0 t ha-1 & 15.3 & 5.0 & 832.5 & 3.03 \\
\hline 125\% RDN & 17.3 & 6.5 & 941.3 & 3.03 \\
\hline 125\% RDN + FYM @ 5.0 t ha-1 & 18.0 & 6.7 & 1045.0 & 3.13 \\
\hline
\end{tabular}




\begin{tabular}{|c|c|c|c|c|}
\hline $\operatorname{SEm}( \pm)$ & 0.6 & 0.2 & 25.2 & 0.1 \\
\hline $\mathrm{CD}(\mathrm{P}=0.05)$ & 1.8 & 0.6 & 75.9 & 0.4 \\
\hline $\mathrm{CV}(\%)$ & 8.2 & 8.1 & 7.1 & 9.6 \\
\hline \multicolumn{5}{|c|}{2015} \\
\hline Control & 7.6 & 2.0 & 513.8 & 2.48 \\
\hline $100 \%$ RDN & 14.9 & 4.7 & 802.5 & 2.78 \\
\hline 100\% RDN + FYM @ 5.0 t ha ${ }^{-1}$ & 15.6 & 5.5 & 840.0 & 2.73 \\
\hline $125 \%$ RDN & 17.6 & 6.9 & 966.8 & 3.18 \\
\hline 125\% RDN + FYM @ 5.0 t ha ${ }^{-1}$ & 18.8 & 7.0 & 1015.0 & 3.28 \\
\hline $\operatorname{SEm}( \pm)$ & 0.6 & 0.1 & 63.4 & 0.2 \\
\hline $\mathrm{CD}(\mathrm{P}=0.05)$ & 1.9 & 0.3 & 191.2 & 0.4 \\
\hline $\mathrm{CV}(\%)$ & 8.5 & 4.3 & 7.9 & 9.4 \\
\hline
\end{tabular}

Table 2: Grain yield and stover yield of foxtail millet as influenced by different integrated nutrient management practices during 2014 and 2015 kharif

\begin{tabular}{|c|c|c|c|c|}
\hline \multirow[b]{2}{*}{ Treatments } & \multicolumn{2}{|c|}{2014} & \multicolumn{2}{|c|}{2015} \\
\hline & Grain yield $\left(\mathrm{kg} \mathrm{ha}^{-1}\right)$ & Stover yield $\left(\mathrm{kg} \mathrm{ha}^{-1}\right)$ & Grain yield $\left(\mathrm{kg} \mathrm{ha}^{-1}\right)$ & Stover yield $\left(\mathrm{kg} \mathrm{ha}^{-1}\right)$ \\
\hline Control & 1666 & 2881 & 1719 & 3187 \\
\hline $100 \%$ RDN & 2099 & 4167 & 2120 & 4262 \\
\hline $100 \%$ RDN + FYM @ $5.0 \mathrm{t} \mathrm{ha}^{-1}$ & 2356 & 4630 & 2441 & 4655 \\
\hline $125 \% \mathrm{RDN}$ & 2627 & 4600 & 2633 & 4812 \\
\hline $125 \%$ RDN + FYM @ $5.0 \mathrm{t} \mathrm{ha}^{-1}$ & 2701 & 4805 & 2708 & 4825 \\
\hline $\operatorname{SEm}( \pm)$ & 40.9 & 111.5 & 46.3 & 67.6 \\
\hline $\mathrm{CD}(\mathrm{p}=0.05)$ & 123 & 157.7 & 139 & 203 \\
\hline CV $(\%)$ & 3.8 & 4.9 & 3.9 & 5.1 \\
\hline
\end{tabular}

Table 3: Gross returns $\left(\mathrm{Rs} \mathrm{ha}^{-1}\right)$, Net returns returns $\left(\mathrm{Rs} \mathrm{ha}^{-1}\right)$ and $\mathrm{BC}$ ratio of foxtail millet as influenced by different integrated nutrient management practices during 2014 and 2015 kharif

\begin{tabular}{|c|c|c|c|c|c|c|}
\hline \multirow{2}{*}{ Treatments } & \multicolumn{3}{|c|}{2014} & \multicolumn{3}{|c|}{2015} \\
\hline & Gross returns & Net returns & BC ratio & Gross returns & Net returns & BC ratio \\
\hline Control & 41650 & 22950 & 1.23 & 42975 & 24275 & 1.30 \\
\hline $100 \%$ RDN & 52475 & 33250 & 1.73 & 53000 & 33775 & 1.76 \\
\hline $100 \%$ RDN + FYM @ 5.0 t ha $^{-1}$ & 58900 & 34675 & 1.43 & 61000 & 36775 & 1.52 \\
\hline $125 \%$ RDN & 65675 & 46250 & 2.38 & 65750 & 46325 & 2.38 \\
\hline $125 \%$ RDN + FYM @ 5.0 t ha $^{-1}$ & 67500 & 43150 & 1.77 & 69500 & 45150 & 1.85 \\
\hline
\end{tabular}

Table 4: Effect of integrated nutrient management practices on agronomic $\mathrm{N}$ use efficiency $\left(\mathrm{AE}_{\mathrm{N}}\right)$ and nitrogen recovery efficiency $\left(R_{N}\right)$ of foxtail millet during wet season 2014-15 and 2015-16

\begin{tabular}{|c|c|c|c|c|}
\hline \multirow{3}{*}{ Treatments } & \multicolumn{2}{|c|}{2014} & \multicolumn{2}{|c|}{2015} \\
\hline & $\mathbf{A \mathbf { E } _ { \mathbf { N } }}$ & $\mathbf{R E}_{\mathbf{N}}$ & $\mathbf{A E}_{\mathbf{N}}$ & $\mathbf{R E}_{\mathbf{N}}$ \\
\hline & $\left(\mathrm{kg} \mathrm{kg}^{-1}\right)$ & $\left(\mathrm{kg} \mathrm{kg}^{-1}\right)$ & $\left(\mathrm{kg} \mathrm{kg}^{-1}\right)$ & $\left(\mathrm{kg} \mathrm{kg}^{-1}\right.$ \\
\hline Control & 0.0 & 0.0 & 0.0 & 0.0 \\
\hline $100 \%$ RDN & 10.8 & 0.19 & 10.0 & 0.18 \\
\hline 100\% RDN + FYM @ $5.0 \mathrm{t} \mathrm{ha}^{-1}$ & 10.6 & 0.13 & 11.1 & 0.14 \\
\hline $125 \% \mathrm{RDN}$ & 19.2 & 0.35 & 18.3 & 0.35 \\
\hline $125 \%$ RDN + FYM @ $5.0 \mathrm{t} \mathrm{ha}^{-1}$ & 13.8 & 0.27 & 13.2 & 0.27 \\
\hline
\end{tabular}

\section{References}

1. Bhattacharyya R, Sachdev MS, Uppal KS, Narayanaswamy G, Datta SP, Singh AK. Effect of nitrogen $N$ 15-labeled urea application alone and in combination with FYM and green manure on yield and nitrogen use efficiency byrice. Journal of the Indian Society of Soil Science. 2006; 54:500-504

2. Basavarajappa R, Prabhakar AS, Halikatti SI. Effect of tillage, organics, nitrogen and their interaction on yield attributes and yields of foxtail millet (Setaria italica) under shallow alfisols during rainy season. Indian Journal of Agronomy. 2002; 47(3): 390-397.

3. Divya S, Maurya BM. Response of kodo millet (Paspalum scrobiculatum) to varying levels of nitrogen under rainfed condition. International Journal of Scientific Research. 2013; 2(8):10-11.

4. Hasan MS, Rashid MH, Rahman QA, Almamun MH. Influence of seed rates and levels of NPK fertilizers on dry matter accumulations and yield performance of foxtail millet (Setaria italica L. Beauv.). Bangladesh Journal of Agricultural Research. 2013; 38(4):689- 704.

5. Kalaghatagi S, Jirali DI, Walia SY, Nagod MS. Response of foxtail millet (Setaria italica) to nitrogen and phosphorous under rainfed conditions of northern dry zone of Karnataka. Annals of Arid zone. 2000; 39(2):169-171.

6. Munirathnam P, Reddy A, Sambasiva, Sawadhkar SM. Evaluation of foxtail millet varieties under low fertility conditions. Agricultural Science Digest. 2006; 26(3):197199.

7. Turgut I, Duman A, Weitgrefe GW, Acikgoz E. Effect of seeding rate and nitrogen fertilization on proso millet under dryland and irrigated conditions. Journal of Plant Nutrition. 2006; 29(12):2119-2129. 